\title{
Long-term forest cover changes, within an agricultural region, in relation to environmental variables, Lubelskie province, Eastern Poland
}

\author{
Wojciech Zgłobicki $^{1}{ }^{1} \cdot$ Leszek Gawrysiak $^{1} \cdot$ Bogusława Baran-Zgłobicka $^{1} \cdot$ \\ Małgorzata Telecka ${ }^{1}$
}

Received: 17 January 2016/ Accepted: 13 October 2016/Published online: 19 October 2016

(C) The Author(s) 2016. This article is published with open access at Springerlink.com

\begin{abstract}
Land cover changes result mainly from anthropogenic determinants (historical and socio-economic processes), but natural factors may also play an important role. The processes of deforestation and reforestation are important elements of present-day landscape changes in Central Europe. In this study, the relation of forest cover changes to environmental variables (topography and soils) within an important agricultural region of Poland, the Lubelskie province $\left(25,000 \mathrm{~km}^{2}\right)$, over the last 180 years was assessed. Three topographical maps (from 1830, 1930 and 2006) and other cartographic data were used to detect forest cover changes and their driving forces. Simple spatial index and supplementary statistical methods were applied to evaluate the relations. The first period (1830-1930) saw intensive deforestation as a result of increasing agricultural land use; forest cover decreased from 30 to $19 \%$. The second period (1930-2006) was characterised by an increase in forest area that now accounts for $23 \%$ of the province. Although changes in forest cover are related to human activity, spatial patterns of deforested and reforested areas during the last 180 years corresponded to the diversity of environmental variables. Flat areas covered by fertile soils were deforested, while new forests appear mainly within sandy soils and steeper slopes. The study also showed that environmental variables had an impact on the structure of forest cover.
\end{abstract}

Keywords Forest cover changes - Topography · Soils . GIS · Historical maps · E Poland

Wojciech Zgłobicki

wojciech.zglobicki@umcs.pl

1 Faculty of Earth Sciences and Spatial Management, Maria Curie-Skłodowska University, Lublin, Poland

\section{Introduction}

Changes in land cover, including forest cover, are among the most distinct effects of human activity on the environment. The increase in forest area recorded nowadays is the most prominent land cover change in Europe (i.a. Falcucci et al. 2007; Feranec et al. 2010; Brouwer et al. 2012). In the past, the main deforestation factor was the transformation of forests into agricultural land. Maruszczak (1952) estimated that forest cover in Poland had decreased from 80 to $28 \%$, over the previous 5000 years. In the twentieth century, in many European countries, including Poland, a new trend has appeared: an increase in forestland area as a result of spontaneous reforestation in areas that ceased to be used agriculturally as well as planned activities (Feranec et al. 2010).

Understanding the historical factors behind the changes in forest cover is significant, from the practical perspective, because it may help to predict future trends. The important role of forests in the landscape is reflected in the large number of recently published studies concerning various aspects of the problem: (1) the prehistoric deforestation of Europe (Kaplan et al. 2009); (2) changes in forest cover in Central European countries (Orczewska 2009; Wulf et al. 2010); (3) contemporary changes in forest cover (Southworth et al. 2002; Kozak et al. 2007a, b; Feranec et al. 2010; Mazgajski et al. 2010). Socio-economic factors are commonly identified as the main driving forces behind changes in land use and land cover (Iverson 1988; Liu et al. 2011; Kumar et al. 2013). Attention was also paid to the role of natural factors (Hietel et al. 2004; Zgłobicki and Baran-Zgłobicka 2012; Havlícek and Chrudina 2013).

Changes in forest cover within the Lubelskie province between 1830 and 1930 were studied by Maruszczak in the mid-twentieth century (Maruszczak 1952), who analysed 
changes in forest cover within districts. However, due to the lack of adequate cartographic material, assessment of the impact of individual factors on this process could only have a qualitative character. The development of GIS tools has now enabled the processing (digitizing) of historical maps and assessment of changes in the forest cover of vast areas over long periods of time.

The Lubelskie province is a major agricultural region characterised by the large diversity of its determinants of land cover. As it is a highly agricultural region, the very important role of socio-economic factors can be expected. It is interesting, however, to what extent changes in forest cover determined by these processes are linked to geological, topographic, and soil conditions (including quality of soils). The relation of forest cover changes to environmental variables is important from the point of view of soil and gully erosion, risk of floods, and transfer of pollutants in the environment. Studies on the role of natural factors in changes to forest cover conducted in Poland so far have focused on mountain areas (Kozak et al. 2007a, b; Ciupa et al. 2015). Within these regions intense deforestation was observed in the nineteenth and twentieth century while in its second half a new process started-reforestation, as a result of land abandonment.

The study focused on the environmental variables because detailed socio-economic data for such long period of time did not exist. Only the relation of forest cover changes to the selected natural factors was studied. The key objectives of the study are as follows: (1) to analyse longterm forest cover changes over a vast area (the Lubelskie province); (2) to look at the impact of environmental variables on forest cover changes; (3) to find regional tendencies in forest cover changes.

The results of the study can be the basis for forecasting the trends and spatial pattern of forest cover changes in the agricultural areas of E Poland and similar regions in Central Europe. They can serve as a model of land cover changes related to the different stages of economic development. It includes also the processes of the forest transition: deforestation and reforestation of the same area. The study answers the question whether natural factors still play a significant role in forest cover changes under conditions of agricultural land use over the centuries. Intensive land cover changes are observed nowadays in Central Europe, and it is very important to understand the driving forces behind them. Long-term landscape changes can have a positive or negative impact from the perspective of sustainable development. Studies investigating such a vast agricultural region over a period of nearly 200 years have not been conducted in Central Europe so far.

\section{Materials and methods}

\section{Study area}

The Lubelskie province is located in E Poland (Fig. 1). It covers nearly $25,000 \mathrm{~km}^{2}$ and is inhabited by more than 2.1 million people. Population density for the province ( 84 people $/ \mathrm{km}^{-2}$ ) is lower than the national average (124 people $/ \mathrm{km}^{-2}$ ). About $46 \%$ of inhabitants live in towns and cities. Thanks to the occurrence of fertile soils the province is an important agricultural region in Poland (major crops are: wheat, sugar beet, fruits and vegetables). Agricultural land covers $56 \%$ of the province area (the average for Poland-48\%).

The environment of the province is diversified from the point of view of abiotic and biotic components. Old-glacial lowlands occur in the northern $(\mathrm{N})$ part of the province while loess and limestone uplands occur in the central and the south-eastern (SE) part. The south-western (SW) part is occupied by an old-glacial plain (sub-Carpathian basins). Quaternary deposits occur in the form of a continuous cover (up to $150 \mathrm{~m}$ thick) in the $\mathrm{N}$ part and within the subCarpathian depression. In the central part Quaternary deposits are found mainly in river valleys and in the form of loess patches of a frequently considerable thickness (Harasimiuk et al. 2008).

Forests of the Lubelskie province show considerable diversity in terms of distribution and size of forest complexes and most of all in terms of habitats and phytosociology: 81 forest and forest-and-shrub associations occur here (Fijałkowski 1993). According to official statistics, forests cover only $23 \%$ of the area (the average for Poland: $30 \%$; Statistical Yearbook of Lubelskie Voivodship 2013). The main species are: pine (69\%), oak (13.5\%) birch (6.8\%), hornbeam (3\%), alder $(2.8 \%)$, and beech $(1.6 \%)$. Coniferous forests are the most important forest community (Vaccinio-Piceetea-65\%), while oak-hornbeam forests (Querco-Fageteai) cover $30 \%$ and alder fern forests (Alneteaglutinosae) $5 \%$.

\section{Maps}

Analytical maps of forest cover were derived from old topographical military maps and present-day data. Three sources were used to analyse changes in forest cover:

(a) Topograficzna Karta Królestwa Polskiego (a Topographic Map of the Polish Kingdom), 1:126,000 (ca. 1830, published in 1843); 14 sheets were used.

(b) Mapa Taktyczna Polski (a Tactical Map of Poland), 1:100,000 (ca. 1930, published in 1935); 30 sheets were used. 


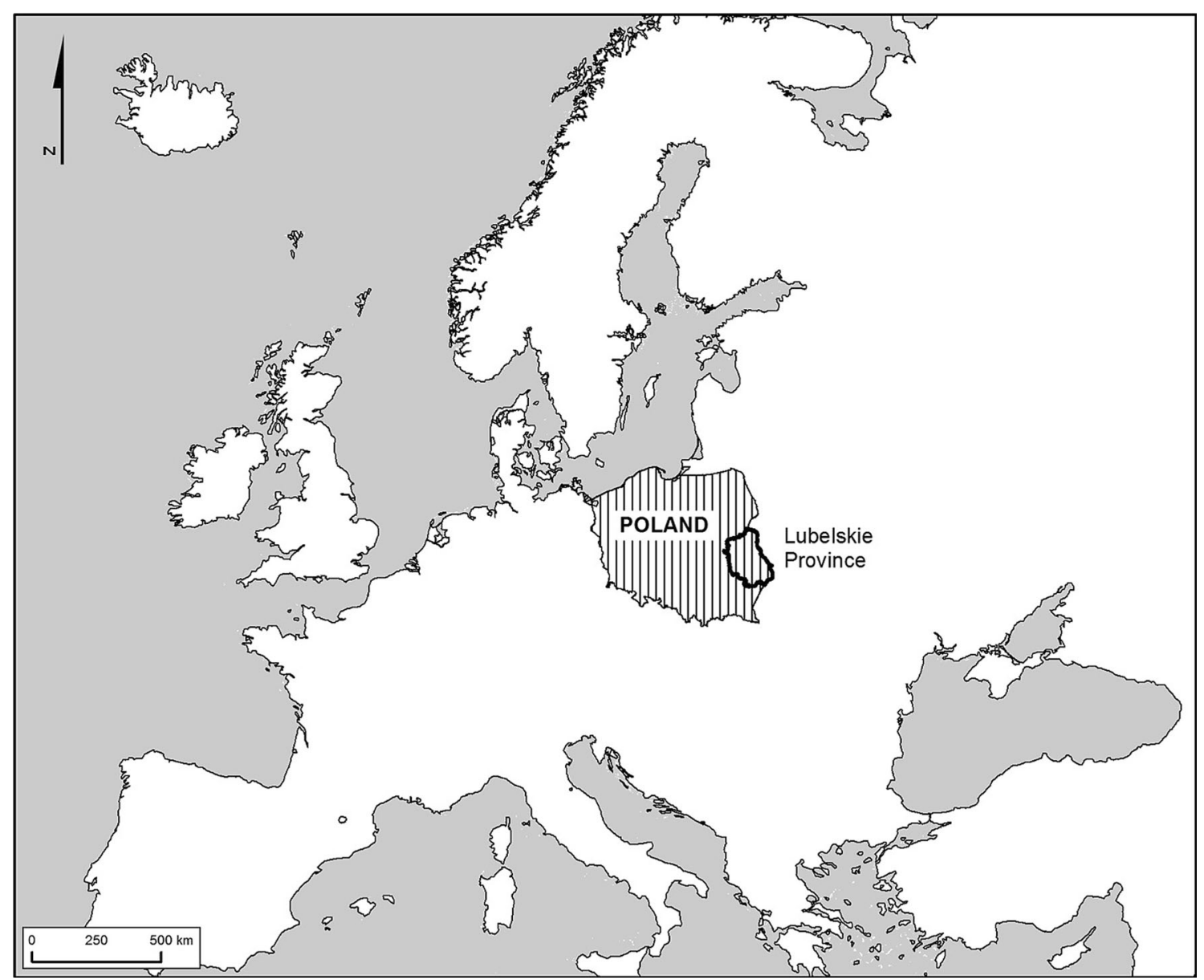

Fig. 1 Location of the Lubelskie province

(c) Corine Land Cover (CLC), 1:100,000 (published in 2006).

Data concerning environmental variables was obtained from the following sources:

1. Digital Terrain Model (DTED LEVEL2, vertical accuracy $12 \mathrm{~m}$, pixel size $30 \mathrm{~m}$ );

2. Mapa glebowo-rolnicza, województwo lubelskie (An agricultural soil suitability map of Lubelskie province, published in 1991) 1:100,000;

3. Map of gullies of the Lublin Region, 1:10,000 (Gawrysiak, unpublished data).

CLC and DTED LEVEL2 data were available in digital format. Historical topographical maps were digitized and transformed into an ArcGIS environment; their vertical accuracy calibration was about $100 \mathrm{~m}$. Two general environmental variables (driving forces) of forest cover change were analysed: topography and soils. A map of slopes was prepared on the basis of DEM. It includes four categories: (1) $0-3^{\circ}$ (flat areas, very suitable for agriculture, (2) $3-6^{\circ}$ (gentle slopes, areas suitable for agriculture), (3) 6-12 ${ }^{\circ}$ (moderate slopes, anti-erosional tillage should be applied), and (4) $>12^{\circ}$ (areas not suitable for agriculture). Additional environmental variables, related to land relief, were separated into two categories: (1) gullies and; (2) bottoms of valleys. Four categories of soil texture were used: (1) sands; (2) silts; (3) clays; and (4) loess. Seven categories of soil types and eight categories of soil quality were analysed. Data for soils were taken directly from an Agricultural soil suitability map of Lubelskie province, 1:100,000. Information on soil quality was only available for nonforested areas (quality of soils is related to their properties and climatologic, hydrologic and geomorphic situation). On this basis we prepared a database of the environment of the province and described the spatial extent of forest cover, forest cover changes, and selected natural factors.

\section{Statistical analyses}

Analysis on forest cover changes during three periods (1830-1930, 1930-2006, and 1830-2006) were carried out. Spatial relation of forest cover changes and environmental variables for the entire province was analysed. For the each 
topographical and soil category, and time period, the area of deforested and reforested land was calculated. Simple index to assess the intensity of forest cover changes within the area covered by a particular natural factor was proposed (1).

$D_{n}=\left(C_{n}: C_{t}\right) /\left(S_{n}: S_{t}\right)$

$D_{n}$ the index of forest cover changes for analysed environmental factor (e.g. slope, soil texture, soil quality); $C_{n}$ change of forest cover within the area of analysed factor [\%]; $C_{t}$ change of forest cover within the entire province [\%]; $S_{n}$ total area of factor within the province $\left[\mathrm{km}^{2}\right] ; S_{t}$ area of the province $\left[\mathrm{km}^{2}\right] ; D_{n}>1$-more intensive forest cover change, in comparison with the entire province (a factor conducive to deforestation/reforestation); $D_{n}<1-$ less intensive forest cover change, in comparison to the entire province (a factor not conducive to deforestation/ reforestation).

In order to complement the spatial analysis results, the following statistical methods were used: (1) principal component analysis (PCA), (2) cluster analysis (CA), and (3) Pearson's linear correlation coefficients. The PCA was carried out for all deforested and reforested patches for each time bracket. Natural components (categories of soil texture, soil types and quality, topography) whose share of the total deforested or reforested patch size was bigger than $10 \%$ were taken into account. Their number varied from 17 to 23 for particular analyses. The goal of PCA was to determine the existence of a group of factors that had a similar impact on forest cover changes in each of the periods under study. Thanks to the analysis, it was also possible to distinguish the key factors conducive to a specific kind of changes (deforestation or reforestation).
In order to assess the changes in the structure of forest patches selected, spatial metrics were calculated. Patch Analyst extension (ArcView) was used (Elkie et al. 1999) to calculate the following metrics: (1) NumP: the total number of patches in the landscape; (2) MPS: mean patch size; (3) MEDPS: median patch size; (4) ED: edge density, defined as a ratio of patch perimeter and landscape area; (5) MSI: mean shape index, where 1 denotes a circular patch and larger values indicate a more complex patch shape.

Besides the analysis made for the entire province, forest cover changes within 27 geomorphological regions, designated by Maruszczak (1972) were studied. Natural regions were used as test areas with a particular pattern of topographic and soil conditions, and such regions served as a homogenous landscape units. Four natural variables of regions were analysed: (1) the share of areas with a slope gradient of $>6^{\circ}$; (2) gully density; (3) the share of areas with good soils (agricultural soil suitability complex 1, 2 and 3); and (4) the share of areas with poor soils (complex 6, 7 and 8). Cluster analysis was conducted to identify groups of mesoregions with similar topographical and soil properties, spatial metrics of forest patches were also calculated.

\section{Results}

\section{General pattern of forest cover changes}

During the study period forests covered the largest area in 1830 (30\% of the province). Forest complexes were distributed quite evenly over the entire area of the province (Fig. 2). In the second half of the nineteenth century and at
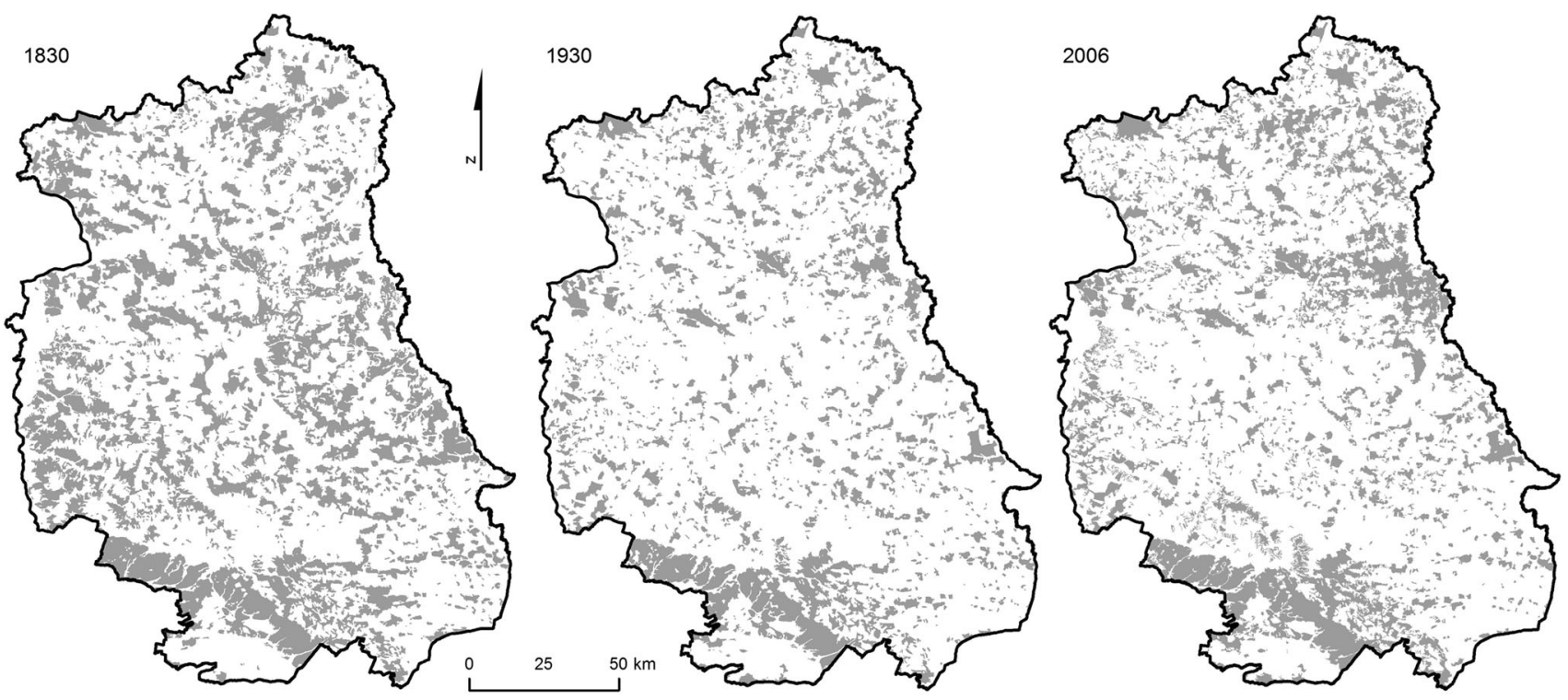

Fig. 2 Forested areas in of the Lubelskie province in 1830, 1930 and 2006 
the turn of the twentieth century, intensive deforestation occurred. The lowest forest cover was recorded in the first half of the twentieth century, and it was $19 \%$ in 1930. Larger forest complexes were preserved, only in the southern (S) part of the province. In the second half of the twentieth century, the area covered by forests began to increase, and the current forest cover was $23 \%$ of the province area. Larger forest patches occur in the $\mathrm{S}$ and $\mathrm{NE}$ parts (Fig. 2).

In the last 180 years, almost $3000 \mathrm{~km}^{2}$ of forests disappeared, while almost $2000 \mathrm{~km}^{2}$ of new forests appeared thanks to reforestation, mainly in the second half of twentieth century (Figs. 3, 4). Throughout the study period about $3270 \mathrm{~km}^{2}$ were covered by stable forests. The largest continuous forest complex has been preserved within the Sandomierz Basin, filled with sandy deposits.

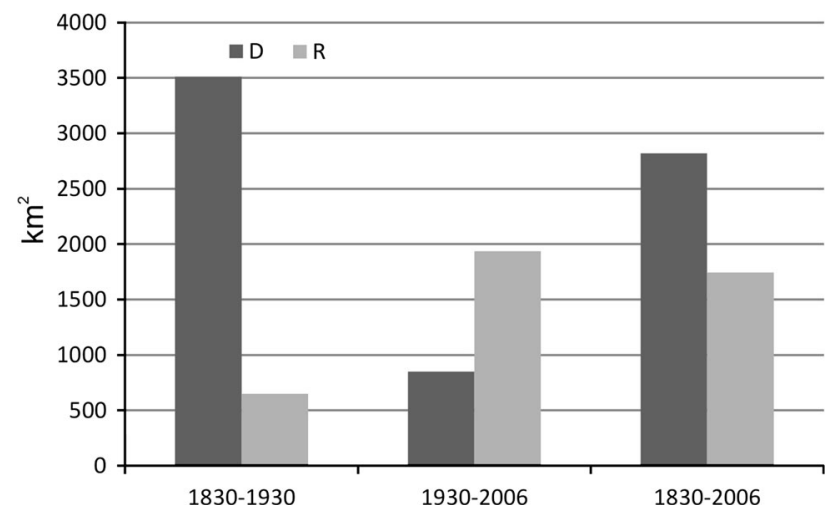

Fig. 3 Forest cover changes in Lubelskie province in three time periods. D—deforested areas, $\mathrm{R}$-reforested areas
Changes in forest cover between 1830 and 2006 varied spatially and temporally (Figs. 3, 4). Intensive deforestation occurred between 1830 and 1930, mainly in the central part of the province, while reforestation was very limited, mainly in the north-eastern part. The period between 1930 and 2006 was characterised by homogeneous deforestation and reforestation, as well as supplementation of the existing forests; $75 \%$ of new forests were located less than $0.5 \mathrm{~km}$ away from existing ones. Reforestation occurred mainly in the $\mathrm{S}$ and NE parts of the province. Data for the period between 1830 and 2006 indicate considerable deforestation in the central part and reforestation, mainly in the NE and S parts of the province (Fig. 4).

In the last 180 years, the mean area of forest patches decreased by $45 \%$, reaching the lowest values in 1930. At the same time, the length of patch edges, the complexity of patch shapes and the ecotone area increased. Topography impacts the structure of forest patches (Table 1). The study proved that patches located within steep slopes are smaller and had a more complex shape, in comparison with average values for the province.

\section{The extent and intensity of forest cover changes}

The temporal patterns referred to above are clear, 1830-1930 was a period of deforestation, while from 1930 to 2006 reforestation occurred within the province. Therefore, in the case of deforestation, indices for the entire period (1830-2006) are very similar to those for the 1830-1930 time bracket. In the case of reforestation indices for the 1830-2006 and 1930-2006 time brackets are similar.

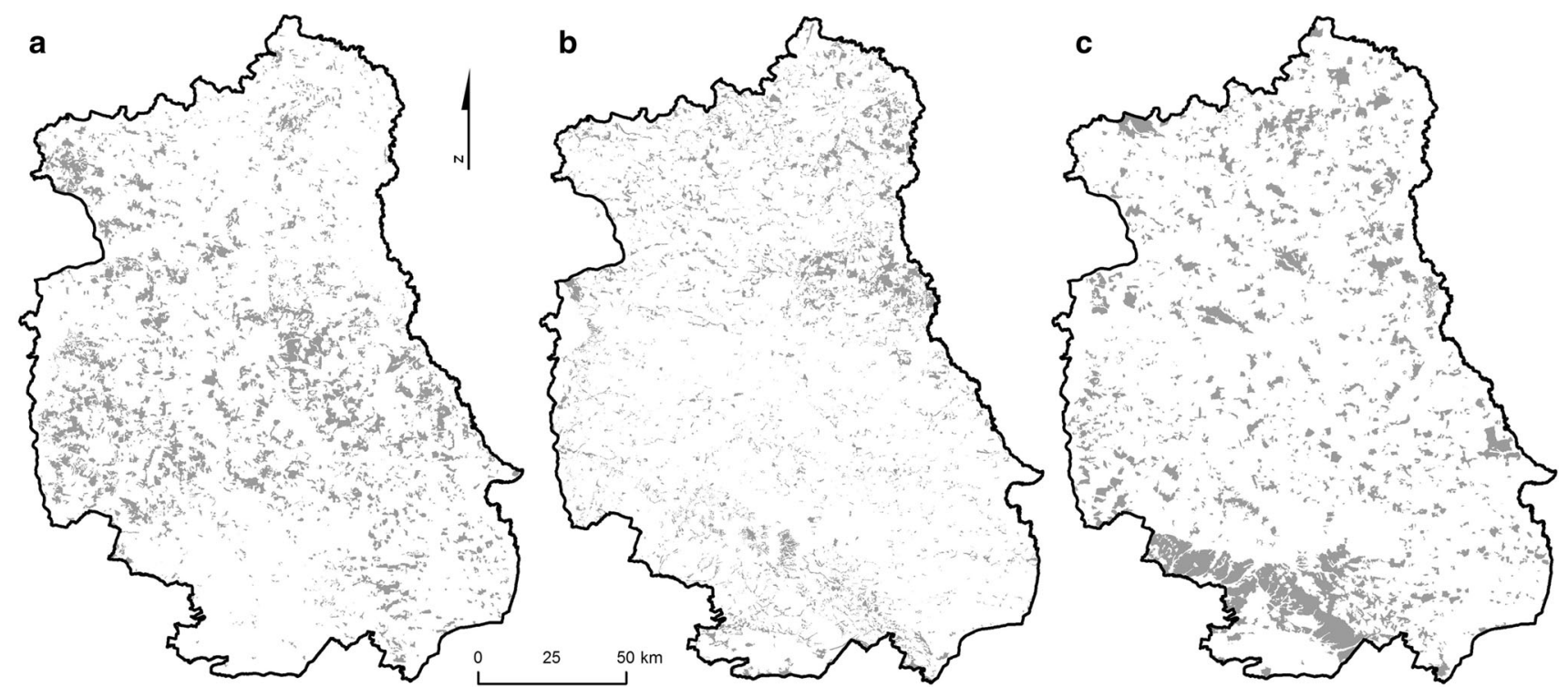

Fig. 4 Changes in forest cover in the Lubelskie province during the in the period 1830-2006. a deforested areas in the period 1830-2006 (comparison of maps from 1830 and 2006), b reforested areas in the period 1830-2006 (comparison of maps from 1830 and 2006), c stable forests (forests existed in 1830, 1930 and 2006) 
Table 1 Temporal changes in the structure of forest patches

\begin{tabular}{lcccl}
\hline Parameters of forest patches & 1830 & 1930 & 2006 & Stable forests \\
\hline Number of patches (NumP) & $1200(112)$ & $1388(127)$ & $1673(150)^{\mathrm{b}}$ & 1374 \\
Mean patch size (MPS) [ha] & $622(364)$ & $332(170)$ & $340(152)$ & 237 \\
Median patch size (MEDPS) [ha] & $80(75)$ & $79(74)$ & $65(60)$ & 47 \\
Edge density (ED) [m/ha] & $20(39)$ & $24(42)$ & $32(77)$ & 29 \\
Mean shape index (MSI) & $1.56(1.80)$ & $1.48(1.87)$ & $1.99(2.75)$ & 1.67 \\
Ecotone area $^{\mathrm{a}}[\%]$ & $23.1(30.7)$ & $22.5(31.2)$ & $30.7(45.3)$ & 28.9 \\
\hline
\end{tabular}

${ }^{a}$ Ecotone area (50 $\mathrm{m}$ from the edge) in relation to the total area of the patch

${ }^{\mathrm{b}}$ In brackets data for forest patches within steep slopes $\left(>6^{\circ}\right)$

Relationship between the intensity of forest cover changes and types of soil texture was found. Deforestation was more intensive within loess covers $\left(D_{\text {def }}\right.$ $1830-2006=1.4)$, while reforestation was very limited $\left(D_{\text {ref }} 1830-2006=0.5\right)$. On the other hand, sandy areas were very much more intensively reforested in comparison to the entire province (Fig. 5).

The highest deforestation, in terms of area, occurred in flatlands prevalent in the province. But, gentle and moderate slopes were deforested more intensively. Moderate and particularly steep slopes were also reforested more intensively (Fig. 5). Within slopes with gradients of more than $6^{\circ}$ the size of reforested areas was greater than that of deforested areas. It was particularly visible on steep slopes (more than $12^{\circ}$ ) where the reforested/deforested area ratio was $5: 1$ and the $D_{\text {ref }}$ index for the 1830-1930 period was 3.70 . Gullies and their adjoining areas were intensively reforested. $D_{\text {ref }}$ index, for the 1830-2006 period, was 2.61. Nowadays, these areas are practically the only forest patches within the agriculturally used loess uplands. Forests covered a similar area within the valley bottoms, i.e. about $14.5 \%$, in 1830 and 2006. In 1930 forests cover only $9.5 \%$ of valley bottoms. Deforestation was observed in the first period. It was, however, less intense compared to the entire province and reforestation was observed in the second period (Fig. 5).

The decrease in forest cover occurred mainly on Arenosols and Podzols, Cambisols, and Luvisols. Deforestation within Chernozems was very limited. The intensity of the process was the highest for Arenosols and Podzols, Cambisols and Luvisols, and Rendzic Leptosols. Reforestation took place, only within Arenosols and Podzols (Table 2). Deforestation occurred mainly within areas with second, fifth, and sixth class soils $(21,14$ and $16 \%$ of the area deforested, from 1830 to 2006). The intensity of deforestation was higher in areas with seventh and third class of soils quality (Fig. 5). There was a lack of direct data on soil quality in reforested areas, but the intensively reforested Arenosols and Podzols mostly belong to the sixth and seventh soil complex.

PCA confirmed the results of spatial analyses. Deforestation in the 1830-1930 and 1830-2006 periods affected areas with low slope gradients, covered by Arenosols and Podzols of the fifth and seventh soil complex. In a case of reforestation in all periods significant correlations between natural factors within reforested areas occurred.

\section{Changes in forest cover in geomorphological mesoregions}

Deforestation processes occurred in most (19 of 27) of analysed geomorphological mesoregions. In 12 mesoregions forest cover fell by more than 10 percentage points in the years 1830-2006. Forest cover increased in eight mesoregions, but only in one case was the increase greater than 10 percentage points. The most deforested regions had a high share of good soils, as well as diverse topography (loess areas). Regions with a high forest cover were characterised by a large share of poor soils or diverse topography (and good soils). Some regions with similar environmental characteristics showed different trends in forest cover changes, in the years 1830-2006, which usually resulted from a lack of reforestation. Based on the Chisquare test it was found that both environmental driving forces (type of soils and slope gradients) as well as factors related to forest cover and its changes, in the chosen periods, showed statistical variation. This means that the mesoregions identified can be joined into groups (clusters) in order to search for certain correlations between the parameters that describe them.

Six groups of mesoregions with similar characteristics were identified (Tables 3,4). The strongest deforestation was found in mesoregions allocated to group 3, characterised by a medium share of good soils $(30 \%)$ and a rather limited diversity of land relief. The dynamics of this process were smaller in areas with a much greater share of the best soils (74-77\%) and, concurrently, with steeper slopes and greater gully density (groups 4 and 6). Deforestation was not very extensive in group 1 despite the high share of good soils. The least intensive deforestation occurred in group 5 , characterised by high gully density and a high share of steep slopes, and in group 2, with a very small share of good soils, accompanied by less varied land relief. 


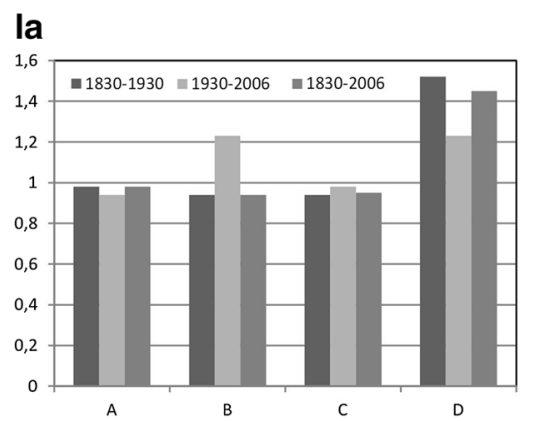

Ila

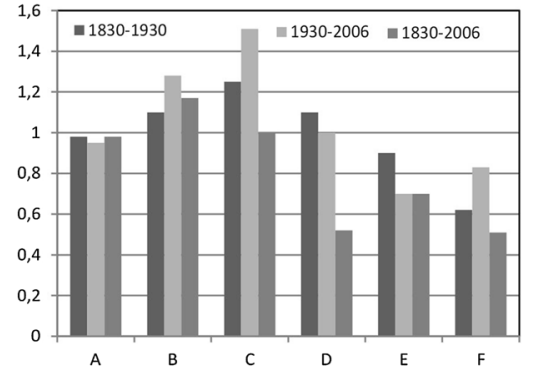

IIla

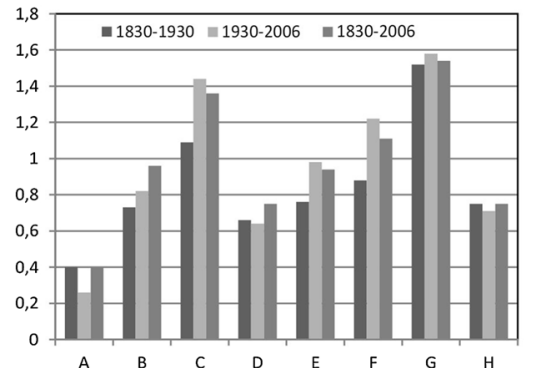

Ib

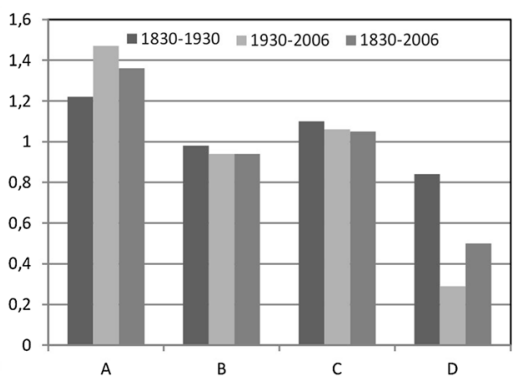

IIb

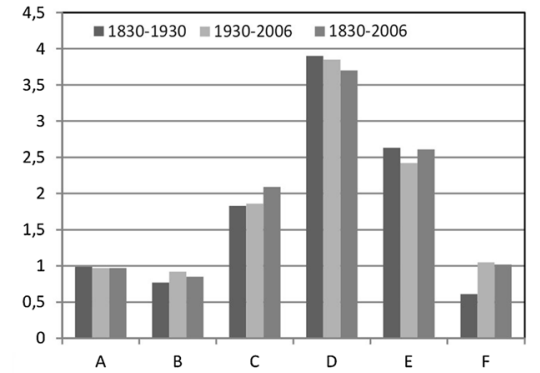

Ic

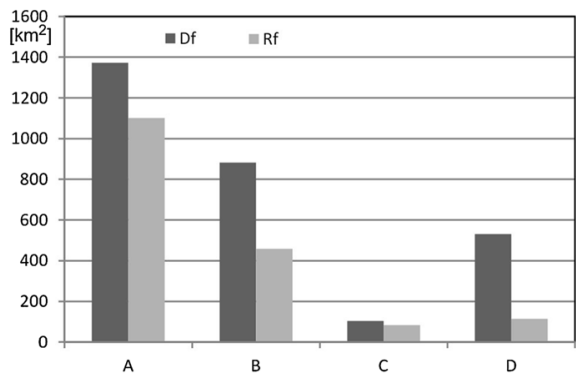

IIc

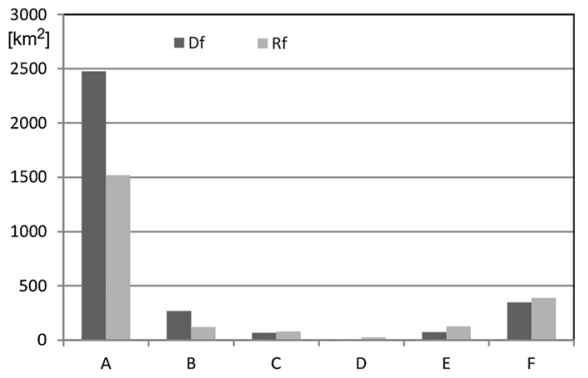

IIIb

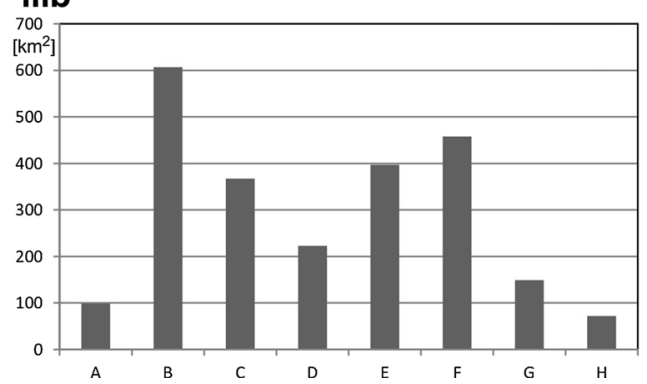

Fig. 5 Intensity of deforestation against topography and soils. I. Soil texture, A—sands, B - silts, C-clays, D—loess; Ia index of intensity of changes for deforested areas, Ib index of intensity of changes for reforested areas, Ic deforested and reforested areas within specific category of soil texture for the time period 1830-2006, Dfdeforested areas, $\mathrm{Rf}-$ reforested areas; IIa Topography, $\mathrm{A}-0-3^{\circ}$, $\mathrm{B}-3-6^{\circ}, \mathrm{C}-6-12^{\circ}, \mathrm{D} \longrightarrow>12^{\circ}, \mathrm{E}-$ gullies, F-Bottoms of valleys; IIa index of intensity of changes for deforested areas, IIb index of

intensity of changes for reforested areas, IIc deforested and reforested areas within specific category of topography for the time period 1830-2006, Df-deforested areas, Rf-reforested areas; III. Quality of soils (soil complexes), A-1st, B-2nd, C-3rd, D-4th, E-5th, F-6th, G-7th, H-8th; IIIa index of intensity of changes for deforested areas; IIIb deforested within specific category of soil quality for the time period 1830-2006
Table 2 Intensity of forest cover changes against soils

\begin{tabular}{lllll}
\hline Soils & \multicolumn{2}{l}{$D_{\text {def }} / D_{\text {ref }}$} & & $\Delta 1830-2006\left[\mathrm{~km}^{2}\right]$ \\
\cline { 2 - 4 } & $1830-1930$ & $1930-2006$ & $1830-2006$ & \\
\hline Arenosols and Podzols & $1.14 / 2.98$ & $0.79 / 3.26$ & $1.09 / 3.24$ & $911^{\mathrm{a}} / 1271^{\mathrm{b}}$ \\
Luvisols and Cambisols & $0.94 / 0.50$ & $0.80 / 0.00$ & $0.88 / 0.00$ & $1378^{\mathrm{a}} / 190^{\mathrm{b}}$ \\
Fluvisols & $0.16 / 0.00$ & $0.31 / 0.00$ & $0.16 / 0.00$ & $23^{\mathrm{a}} / 1^{\mathrm{b}}$ \\
Mollic Gleysols & $0.75 / 0.20$ & $0.85 / 0.00$ & $0.72 / 0.00$ & $143^{\mathrm{a}} / 2^{\mathrm{b}}$ \\
Gleysols and Leptosols & $0.25 / 0.00$ & $0.58 / 0.00$ & $0.24 / 0.00$ & $14^{\mathrm{a}} /<1^{\mathrm{b}}$ \\
Rendzic Leptosols & $1.01 / 0.00$ & $0.63 / 0.00$ & $0.96 / 0.00$ & $166^{\mathrm{a}} /<1^{\mathrm{b}}$ \\
Chernozems & $0.24 / 0.00$ & $0.22 / 0.00$ & $0.23 / 0.00$ & $27^{\mathrm{a}} /<1^{\mathrm{b}}$ \\
\hline
\end{tabular}

$D_{\text {def }}$-index of intensity for deforested areas, $D_{\text {ref }}$-index of intensity for reforested areas

${ }^{\mathrm{a}}$ Deforested areas; ${ }^{\mathrm{b}}$ reforested areas 
Table 3 Characteristics of geomorphological mesoregions of Lublin Province

\begin{tabular}{|c|c|c|c|c|c|c|c|c|c|c|c|c|}
\hline \multirow{2}{*}{$\begin{array}{l}\text { Geomorphological } \\
\text { region }\end{array}$} & \multirow{2}{*}{$\begin{array}{l}\text { Land } \\
\text { relief }\end{array}$} & \multirow[t]{2}{*}{ Group } & \multirow{2}{*}{$\begin{array}{l}\text { Steep } \\
\text { slopes } \\
\left(>6^{\circ}\right) \\
{[\%]}\end{array}$} & \multirow{2}{*}{$\begin{array}{l}\text { Density of } \\
\text { gullies } \\
{\left[\mathrm{km} / \mathrm{km}^{2}\right]}\end{array}$} & \multirow{2}{*}{$\begin{array}{l}\text { Good } \\
\text { soils } \\
{[\%]}\end{array}$} & \multirow{2}{*}{$\begin{array}{l}\text { Poor } \\
\text { soils } \\
{[\%]}\end{array}$} & \multicolumn{3}{|c|}{ Forest cover $[\%]$} & \multicolumn{3}{|c|}{ Changes in forest cover $[\%]^{\mathrm{a}}$} \\
\hline & & & & & & & 1830 & 1930 & 2006 & $1830-1930$ & $1930-2006$ & 1830-2006 \\
\hline Garb Włodawski & Ridge & 2 & 0.07 & 0.00 & 0.00 & 55.60 & 29.93 & 32.81 & 49.06 & 2.88 & 16.25 & 19.13 \\
\hline Grzęda Horodelska & Plateau & 4 & 1.57 & 0.01 & 98.06 & 0.38 & 17.07 & 5.86 & 5.92 & -11.20 & 0.05 & -11.15 \\
\hline Grzęda Sokalska & Plateau & 6 & 6.20 & 0.13 & 97.91 & 0.83 & 18.11 & 8.42 & 7.52 & -9.69 & -0.90 & -10.60 \\
\hline Kotlina Chodelska & Basin & 3 & 0.40 & 0.02 & 24.79 & 40.93 & 46.90 & 19.54 & 28.16 & -27.36 & 8.62 & -18.74 \\
\hline $\begin{array}{l}\text { Kotlina } \\
\text { Hrubieszowska }\end{array}$ & Basin & 1 & 0.12 & 0.00 & 88.78 & 5.75 & 22.72 & 13.27 & 12.94 & -9.45 & -0.32 & -9.77 \\
\hline Kotlina Zamojska & Basin & 4 & 0.43 & 0.02 & 85.75 & 5.41 & 9.78 & 6.63 & 6.34 & -3.15 & -0.28 & -3.44 \\
\hline Pagóry Chełmskie & Hills & 4 & 0.63 & 0.01 & 46.86 & 23.00 & 35.96 & 11.43 & 15.51 & -24.53 & 4.07 & -20.45 \\
\hline $\begin{array}{r}\text { Płaskowyż } \\
\text { Bełżycki }\end{array}$ & Plateau & 5 & 0.93 & 0.12 & 57.60 & 11.64 & 31.45 & 9.48 & 10.50 & -21.96 & 1.02 & -20.95 \\
\hline $\begin{array}{l}\text { Płaskowyż } \\
\text { Łuszczowski }\end{array}$ & Plateau & 1 & 0.26 & 0.01 & 76.69 & 5.73 & 26.77 & 14.36 & 13.43 & -12.42 & -0.93 & -13.35 \\
\hline $\begin{array}{l}\text { Płaskowyż } \\
\text { Nałęczowski }\end{array}$ & Plateau & 6 & 9.69 & 1.37 & 98.02 & 0.41 & 20.34 & 4.88 & 8.58 & -15.45 & 3.70 & -11.75 \\
\hline $\begin{array}{l}\text { Roztocze } \\
\text { Południowe }\end{array}$ & Hills & 6 & 4.66 & 0.39 & 56.13 & 7.68 & 36.88 & 24.10 & 40.42 & -12.77 & 16.32 & 3.54 \\
\hline $\begin{array}{l}\text { Roztocze } \\
\text { Środkowe }\end{array}$ & Hills & 5 & 12.04 & 0.37 & 51.28 & 30.19 & 44.76 & 37.14 & 41.37 & -7.62 & 4.24 & -3.38 \\
\hline $\begin{array}{l}\text { Roztocze } \\
\text { Zachodnie }\end{array}$ & Hills & 5 & 29.75 & 1.84 & 86.41 & 2.74 & 21.24 & 21.12 & 25.77 & -0.12 & 4.65 & 4.53 \\
\hline Równina Bełzka & Plain & 1 & 0.01 & 0.00 & 83.36 & 6.04 & 11.92 & 5.65 & 7.36 & -6.27 & 1.71 & -4.57 \\
\hline $\begin{array}{l}\text { Równina } \\
\text { Biłgorajska }\end{array}$ & Plain & 2 & 0.32 & 0.00 & 5.25 & 63.05 & 52.19 & 49.06 & 53.34 & -3.13 & 4.28 & 1.15 \\
\hline $\begin{array}{l}\text { Równina } \\
\text { Dorohucka }\end{array}$ & Plain & 3 & 0.32 & 0.00 & 38.81 & 27.60 & 28.45 & 6.45 & 10.09 & -22.00 & 3.63 & -18.37 \\
\hline Równina Dubienki & Plain & 3 & 0.05 & 0.00 & 27.65 & 30.43 & 39.97 & 17.71 & 24.15 & -22.26 & 6.44 & -15.82 \\
\hline $\begin{array}{l}\text { Równina } \\
\text { Łukowska }\end{array}$ & Plain & 2 & 0.00 & 0.00 & 2.72 & 44.83 & 24.17 & 22.47 & 26.31 & -1.70 & 3.83 & 2.13 \\
\hline $\begin{array}{l}\text { Równina } \\
\text { Parczewska }\end{array}$ & Plain & 2 & 0.01 & 0.00 & 0.85 & 49.19 & 23.82 & 20.56 & 26.49 & -3.26 & 5.93 & 2.67 \\
\hline $\begin{array}{l}\text { Równina } \\
\text { Sosnowiecka }\end{array}$ & Plain & 2 & 0.09 & 0.00 & 10.18 & 43.33 & 34.32 & 15.23 & 31.70 & -19.09 & 16.47 & -2.62 \\
\hline $\begin{array}{l}\text { Wysoczyzna } \\
\text { Janowska }\end{array}$ & Plateau & 2 & 0.09 & 0.00 & 0.60 & 45.84 & 20.36 & 19.36 & 23.28 & -1.00 & 3.92 & 2.92 \\
\hline $\begin{array}{l}\text { Wysoczyzna } \\
\text { Lubartowska }\end{array}$ & Plateau & 2 & 0.12 & 0.01 & 13.86 & 38.64 & 29.54 & 16.98 & 20.72 & -12.56 & 3.73 & -8.82 \\
\hline $\begin{array}{l}\text { Wysoczyzna } \\
\text { Żelechowska }\end{array}$ & Plateau & 2 & 0.08 & 0.00 & 1.56 & 50.63 & 35.01 & 13.26 & 18.02 & -21.74 & 4.76 & -16.99 \\
\hline $\begin{array}{l}\text { Wzniesienie } \\
\text { Giełczewskie }\end{array}$ & Plateau & 6 & 4.19 & 0.26 & 38.00 & 11.39 & 31.19 & 11.09 & 12.14 & -20.10 & 1.05 & -19.05 \\
\hline $\begin{array}{l}\text { Wzniesienie } \\
\text { Grabowieckie }\end{array}$ & Hills & 6 & 6.52 & 0.41 & 86.40 & 7.53 & 35.69 & 17.21 & 16.49 & -18.48 & -0.72 & -19.20 \\
\hline $\begin{array}{l}\text { Wzniesienie } \\
\text { Urzędowskie }\end{array}$ & Hills & 6 & 3.65 & 0.33 & 65.61 & 9.09 & 40.30 & 17.47 & 20.34 & -22.83 & 2.88 & -19.95 \\
\hline
\end{tabular}

${ }^{a}$ Forest cover at the end of the period minus forest cover at the beginning of the period; good soils (agricultural soil suitability complex 1, 2, and 3 ), poor soils (complex 6,7, and 8) 
Table 4 Basic characteristics of selected groups of mesoregions (mean values)

\begin{tabular}{|c|c|c|c|c|c|c|c|c|c|c|c|c|c|c|}
\hline \multirow[t]{2}{*}{ Group } & \multirow{2}{*}{$\begin{array}{l}\text { Steep } \\
\text { slopes } \\
{[\%]}\end{array}$} & \multirow{2}{*}{$\begin{array}{l}\text { Gullies } \\
{[\mathrm{km} /} \\
\left.\mathrm{km}^{2}\right]\end{array}$} & \multirow{2}{*}{$\begin{array}{l}\text { Good } \\
\text { soils } \\
{[\%]}\end{array}$} & \multirow{2}{*}{$\begin{array}{l}\text { Poor } \\
\text { soils } \\
{[\%]}\end{array}$} & \multicolumn{3}{|c|}{ Forest cover $[\%]$} & \multicolumn{3}{|c|}{ Forest cover changes [\%] } & \multicolumn{4}{|c|}{ Structure of patches (2006) } \\
\hline & & & & & 1830 & 1930 & 2006 & $1830-1930$ & 1930-2006 & 1830-2006 & $\begin{array}{l}\text { Mean } \\
\text { [ha] }\end{array}$ & $\begin{array}{l}\text { Median } \\
\text { [ha] }\end{array}$ & $\begin{array}{l}\text { Edge } \\
\text { density }\end{array}$ & MSI \\
\hline 1 & 0.13 & 0.01 & 82.94 & 5.73 & 20.47 & 11.09 & 11.24 & -9.38 & 0.15 & -9.23 & 235.86 & 79.23 & 32.84 & 1.63 \\
\hline 2 & 0.10 & 0.00 & 4.38 & 48.38 & 31.17 & 23.72 & 31.12 & -7.45 & 7.40 & -0.05 & 603.79 & 58.02 & 31.63 & 2.00 \\
\hline 3 & 0.26 & 0.01 & 30.42 & 32.33 & 38.44 & 14.57 & 20.80 & -23.87 & 6.23 & -17.64 & 346.70 & 120.01 & 36.25 & 1.98 \\
\hline 4 & 0.88 & 0.01 & 76.89 & 9.97 & 20.94 & 7.98 & 9.26 & -12.96 & 1.28 & -11.68 & 180.67 & 50.84 & 40.07 & 1.74 \\
\hline 5 & 14.24 & 0.78 & 65.10 & 14.67 & 32.48 & 22.58 & 25.88 & -9.90 & 3.30 & -6.60 & 328.69 & 61.31 & 53.43 & 2.33 \\
\hline 6 & 5.82 & 0.48 & 73.68 & 5.96 & 30.42 & 13.86 & 17.58 & -16.56 & 3.72 & -12.84 & 225.79 & 57.51 & 49.55 & 1.99 \\
\hline
\end{tabular}

Table 5 Correlation coefficients (Pearson) between forest cover, changes in forest cover and slopes and soils (normalised data for mesoregions)

\begin{tabular}{lrrrrrrr}
\hline & \multicolumn{2}{l}{ Forest cover } & & \multicolumn{2}{l}{ Forest cover changes } \\
\cline { 2 - 3 } & 1830 & 1930 & 2006 & & $1830-1930$ & $1930-2006$ & $1830-2006$ \\
\hline Steep slopes $\left(>6^{\circ}\right)$ & -0.05 & 0.11 & 0.07 & & 0.19 & -0.05 & 0.14 \\
Good soils & -0.43 & -0.50 & -0.60 & & -0.09 & -0.52 & -0.33 \\
Poor soils & 0.46 & 0.61 & 0.67 & & 0.18 & 0.49 & 0.39 \\
Gullies & -0.11 & -0.02 & -0.02 & & 0.11 & -0.01 & 0.09 \\
\hline
\end{tabular}

Good soils (agricultural soil suitability complex 1, 2 and 3), poor soils (complex 6, 7 and 8)
The analysis of relationships between forest patch structure with slopes and soil quality, shows that the largest forest patches occur in areas with; (1) a high share of poor soils and a limited diversity of landforms or, (2) a high share of steep slopes and high gully density. The smallest patches occur in areas with a high share of good soils. Similar patterns were observed in the case of the median. Edge density usually reaches higher values for patches within areas with diverse land relief; the influence of soil is insignificant, in this case. Patch shape diversity (MSI) is also greater in these areas (Table 4).

The occurrence of medium and strong correlations between areas covered by fertile soils (negative correlation) and poor soils (positive correlation) and forest cover and its changes in the analysed period was found. This correlation did not occur for changes in forest cover during the period 1830-1930 (Table 5).

\section{Discussion}

Forests deliver many ecosystem services: they serve as habitats, preserve biodiversity, conserve soils, protect against flood, and constitute a tourist asset. Understanding historical factors behind the changes in the forest cover is significant, from the practical perspective, because it helps predict future trends. Forest cover changes within the province resulted mainly from agricultural land use changes. Although it is difficult to separate human and natural impacts, results of the study indicate that slopes and soils are important factors for agriculture, and their spatial pattern impacts the structure of land use and land cover, within the province. Environmental variables did not changed significantly during the last 180 years. Only changes of climate conditions were observed. Little Ace Age ended in the nineteenth century, and the average annual temperature in Central Europe raised from about $+1-2{ }^{\circ} \mathrm{C}$ (during the last 180 years) (Kundzewicz 2011).

The spatial pattern of changes in forest cover, during the last 180 years, generally corresponded to the spatial diversity of the environment. Deforestation occurred in the central part of the province, within loess uplands covered by fertile soils, while reforestation took place within the $\mathrm{N}$ and S parts. In these parts of the province, sandy lowlands and depression (less fertile soils) or limestone uplands occur, with diversified relief (steeper slopes). Reforestation of deforested areas occurred only in some areas. In our opinion it confirms the impact of slopes and soils on forest cover changes. Deforestation was a massive (uniform) process, while reforestation was more spatially selective.

In the case of the analyses conducted within mesoregions, both soil (soil quality) and slopes influence the area covered by forests. Forest cover was smaller and the scale of deforestation was greater in areas with a high share of good soils. The largest deforestation occurred in mesoregions where slopes and soils jointly created advantageous conditions for the development of agriculture. Under similar soil conditions mesoregions with more diverse land relief had a smaller scale of deforestation. The general conclusion, however, was that soil conditions play a more 
important role than slopes, which was also confirmed by correlation coefficients, although this correlation did not occur in the first of the analysed periods (1830-1930).

Deforestation processes occurred mainly in loess areas, on plateau tops and gentle slopes, covered by Luvisols and Cambisols. Reforestation was characteristic for slopes with higher gradients, in gullies and covered by Arenosols and Podzols. Reforestation was observed primarily in areas with low-quality soils (5-7th complex) which was appropriate from the perspective of using agricultural production space.

Spatial patterns of poor soils influence the occurrence of stable forests during analysed period. About $56 \%$ of the area currently covered by forests had woodlands growing in the same locations 180 years ago. Most of them were located within the $\mathrm{S}$ and $\mathrm{N}$ parts of the province, where less fertile sandy soils appear.

The occurrences of varied land relief (reforestation) and fertile soils (deforestation) were the main natural variables influencing changes in the spatial distribution of forests, in the Lubelskie province, during the studied period. The reason for forest-felling was the transformation of forest land into agricultural land. Nowadays, $90 \%$ of the deforested land is used agriculturally. During the 1830-1930 period, deforestation occurred not only in agriculturally valuable areas, but also in areas with higher slope gradients or poorer soils. It was related to an increasing demand for food, which resulted in the increasing acreage of land used for agriculture. In the second time bracket analysed, these areas underwent reforestation as a result of land abandonment, within terrains not suitable for agriculture.

It was an effect of planned reforestation, mainly in the 1940s and 1950s, but also a result of the natural succession of forest communities, on abandoned land. It seems that the present-day increase in forest-land area will mostly result from the succession of forest communities, into areas excluded from farming (depopulation of rural areas and difficulties in farming). Planned reforestation encompasses only 400-600 hectares of land per year, which accounts for $0.02 \%$ of the area of the province. It is linked to a considerable share of high-quality soils (1st-3rd class) that may not be afforested according to applicable laws. It should be stressed that during the 1830-2006 period, the same area could undergo reforestation followed by deforestation and vice versa.

Despite the growing area of forests in the twentieth century, the structure of forest patches within the province became less favourable from an ecological point of view. Deforestation affected vast areas while reforestation encompassed a large number of small patches. Sparse settlement and a mosaic of land owners is the main cause of forest fragmentation. The mean size of forest patches decreased and the mean length of patch edges and the complexity of patch shape increased. This process commonly occurs around the world and is associated with human activity. Similar patterns were found in Canada (Fuller 2001), Turkey (Çakır et al. 2008) and in central Poland (Mazgajski et al. 2010). Our studies proved that slopes also impact the spatial structure of forest cover. Patches located within steeper slopes are smaller and have more diversified shapes. However, it should be mentioned that within agricultural regions increasing land cover mosaic is a positive phenomenon, even if woodland patches are small.

Maruszczak (1952) indicated the influence of factors such as the occurrence of sandy soils and diverse land relief on the spatial distribution of forests, in the Lubelskie province. In his opinion, however, a much more important role was played by social factors, namely the development of human settlements, their types, and the distribution of towns. The above observations did not have a quantitative character.

The impact of natural factors on forest cover changing over long periods has been discussed by many authors. Havlíček and Chrudina (2013) analysed long-term land use changes, in relation to elevation, slopes and the exposition of slopes in W Slovakia. The most clear relationships were found in the case of analyses concerning land use and slope intervals. The very distinct influence of land relief, type of landforms, and slope gradient on present-day land use in the loess areas of SE Poland was indicated by Zgłobicki and Baran-Zgłobicka (2012). Similar patterns were found in the loess areas of China ( $\mathrm{Fu}$ et al. 2006). The role of slope gradient and elevation above sea level, on the spatial distribution of forests, was also noted in research conducted in central Poland (Ciupa et al. 2015), Germany (Hietel et al. 2004) and the Czech Republic (Opršal et al. 2013). Wulf et al. (2010) found a clear relationship between forest cover changes and soils in NE Germany. Reforestation processes occurred primarily within less productive sandy soils. Iverson (1988) reached similar conclusions, when studying the prairie soils of Illinois (USA). Impact of topography, slopes, and altitude on forest transition in Carpathians was also found by Kozak et al. (2007b).

The recently observed increase in forest area within loess uplands is partially related to the threat of erosion occurring there. This factor can be the driver of land use changes (Bakker et al. 2005). Increased forest-land area, especially within steep slopes and gullies is advantageous from the perspective of flood and soil erosion control (Rodzik et al. 2009; Baran-Zgłobicka and Zgłobicki 2012).

The present-day landscape contains natural and cultural elements. Its changes result from the joint impact of socioeconomic and environmental factors (Bürgi et al. 2004; Hietel et al. 2004, 2005). In most cases the former plays a 
more important role in land use changes. However, research conducted around the world shows that the role of natural factors may be significant, in many cases. The sustainable development of specific areas has to take into account the natural determinants of land use. Analysing the natural conditions of the province Maruszczak (1952) estimated that its optimum forest cover was about $29 \%$. Similar levels are assumed for the entire country in national programmes concerning forest cover. This indicates a need to increase the area of forest land, primarily in areas featuring numerous gullies and having high slope gradients (Baran-Zgłobicka and Zgłobicki 2012). In our opinion, the results of this study may help in forecasting trends in forest cover changes, in the agricultural areas of E Poland, and in similar regions in Central Europe.

\section{Conclusions}

1. Over the last 180 years, two opposing trends have occurred: deforestation (1830-1930) and reforestation (1930-2006). Deforestation was caused by agricultural land use. From the mid-twentieth century, a reverse process occurred, i.e. planned reforestation and forest succession into areas excluded from agricultural use, particularly areas having the lowest value.

2. Environmental variables having the strongest impact on changes in the spatial pattern of forests include the occurrence of high-quality soils and diversified land relief. Deforestation took place mainly within flat areas covered by fertile soils. Steeper slopes and regions characterised by poor soils were reforested. Agricultural land use has corresponded to environmental conditions and spatial pattern of soil cover (quality) was more important for forest cover changes.

3. Slopes and soil quality influence the structure of forest patches. The occurrence of poor soils favours the preservation of large forest patches. Most of them are located on sandy soils. Regions with diverse land relief and good soils are characterised by the occurrence of patches of smaller size and more diverse shape.

4. In our opinion, the increase in the area of forest land, in the future, will mostly result from the succession of forest communities into areas gradually excluded from farming (due to the unfavourable natural conditionspoor soils and steep slopes).

5. Present-day reforestation is a positive process from the environmental point of view and may be an element of sustainable development of the agricultural regions in Central Europe.
Acknowledgments The study was financed with funds for research by the Faculty of Earth Sciences and Spatial Management, Maria Curie-Sklodowska University. The authors wish to thank the anonymous reviewers for their valuable comments and suggestions to improve the quality of this paper.

Open Access This article is distributed under the terms of the Creative Commons Attribution 4.0 International License (http://crea tivecommons.org/licenses/by/4.0/), which permits unrestricted use, distribution, and reproduction in any medium, provided you give appropriate credit to the original author(s) and the source, provide a link to the Creative Commons license, and indicate if changes were made.

\section{References}

Bakker M, Govers G, Kosmas C, Vanackera V, van Oost K, Rounsevell M (2005) Soil erosion as a driver of land-use change. Agric Ecosyst Environ 105:467-481

Baran-Zgłobicka B, Zgłobicki W (2012) Mosaic landscapes of SE Poland: should we preserve them? Agrofor Syst 85:351-365

Brouwer FM, Thomas AJ, Chadwick MJ (2012) Land use changes in Europe: processes of change, environmental transformations and future patterns. Springer Science and Business Media, Berlin, p 529

Bürgi M, Herspeger AM, Schneeberger N (2004) Driving forces of landscape change-current and new directions. Landsc Ecol 19:857-868

Çakır G, Sivrikaya F, Keleş S (2008) Forest cover change and fragmentation using Landsat data in Maçka State Forest Enterprise in Turkey. Environ Monit Assess 137:51-66

Ciupa T, Suligowski R, Wałek G (2015) Morphological and soil determinants of forest cover changes in Świętokrzyski National Park and its buffer zone in the last 200 years. Quaest Geogr 34(1):55-63

Elkie PC, Rempel RS, Carr AP (1999) Patch analyst user's manual: a tool for quantifying landscape structure. NWST technical manual TM-002, Ontario

Falcucci A, Maiorano L, Boitani L (2007) Changes in land-use/landcover patterns in Italy and their implications for biodiversity conservation. Landsc Ecol 22(4):617-631

Feranec J, Jaffrain G, Soukup T, Hazeu G (2010) Determining changes and flows in European landscapes 1990-2000 using CORINE land cover data. Appl Geogr 30:19-35

Fijałkowski D (1993) Lasy Lubelszczyzny. LTN, Lublin

Fu B-J, Zhang Q-J, Chen L-D, Zhao W-W, Gulinek H, Liu G-B, Yang Q-K, Zhu Y-G (2006) Temporal change in land use and its relationship to slope degree and soil type in a small catchment on the Loess Plateau in China. Catena 65:41-48

Fuller DO (2001) Forest fragmentation in Loudoun County, Virginia, USA evaluated with multitemporal Landsat imagery. Landsc Ecol 16:627-642

Harasimiuk M, Nowak J, Superson J (2008) Budowa geologiczna i rzeźba terenu. In: Uziak S, Turski R (eds) Środowisko przyrodnicze Lubelszczyzny. Lubelskie Towarzystwo Naukowe, Lublin, pp 9-74

Havlíček M, Chrudina Z (2013) Long-term land use changes in relations to selected relief characteristics in western Carpathians and western Pannonian basin-case study from Hodonín district (Czech Republic). Carpathian J Earth Environ Sci 8(3):231-244 
Hietel E, Waldhardt R, Otte A (2004) Analysing land-cover changes in relation to environmental variables in Hesse, Germany. Landsc Ecol 19:473-489

Hietel E, Waldhardt R, Otte A (2005) Linking socio-economic factors, environment and land cover in the German Highlands, 1945-1999. J Environ Manag 75:133-143

Iverson LR (1988) Land-use changes in Illinois, USA: the influence of landscape attributes on current and historic landuse. Landsc Ecol 2:45-61

Kaplan JO, Krumhardt KM, Zimmermann N (2009) The prehistoric and preindustrial deforestation in Europe. Quat Sci Rev 28:3016-3034

Kern H, Popiołek E (eds) (1991) Mapa glebowo-rolnicza 1:100,000, województwo lubelskie. Institute for Soil Science and Plant Cultivation (IUNG), Puławy

Kozak J, Estreguil C, Troll M (2007a) Forest cover changes in the northern Carpathians in the twentieth century: a slow transition. J Land Use Sci 22(2):127-146

Kozak J, Estreguil C, Vogt P (2007b) Forest cover changes and pattern changes in the Carpathians over last decades. Eur J For Res 126:77-90

Kumar S, Merwade V, Rao PSC, Pijanowski BC (2013) Characterizing long-term land use/cover change in the United States from 1850 to 2000 using a nonlinear bi-analytical model. Ambio 42:285-297

Kundzewicz ZW (2011) Zmiany klimatu, ich przyczyny i skutkiobserwacje i projekcje. Landf Anal 15:39-49

Liu D, Li B, Liu X, Warrington DN (2011) Monitoring land use change at a small watershed scale on the Loess Plateau, China: applications of landscape metrics, remote sensing and GIS. Environ Earth Sci 64:2229-2239

Mapa Taktyczna Polski 1:100,000 (1935) WIG. Library of Faculty of Earth Sciences and Spatial Management MCSU, Warszawa
Maruszczak H (1952) Stan i zmiany lesistości województwa lubelskiego w latach 1830-1930. Ann UMCS B 5:109-178

Maruszczak H (1972) Wyżyny Lubelsko-Wołyńskie. In: Klimaszewski $\mathrm{M}$ (ed) Geomorfologia Polski tom 1. PWN, Warszawa, pp 340-384

Mazgajski TD, Żmihorski M, Abramowicz K (2010) Forest habitat loss and fragmentation in Central Poland during the last 100 years. Silva Fenn 44(4):715-723

Opršal Z, Šarapatka B, Kladivo P (2013) Land-use changes and their relationships to selected landscape parameters in the cadastral areas in Moravia (Czech Republic). Morav Geogr Rep 21(1):41-50

Orczewska A (2009) Age and origin of forests in South-western Poland and their importance for ecological studies in mandominated landscapes. Landsc Res 34(5):599-617

Rodzik J, Furtak T, Zgłobicki W (2009) The impact of snowmelt and heavy rainfall runoff on erosion rates in a gully system, Lublin Upland, Poland. Earth Surf Process Landf 34:1938-1950

Southworth J, Nagendra H, Tucker C (2002) Fragmentation of a landscape: incorporating landscape metrics into satellite analyses of land-cover change. Landsc Res 27(3):253-269

Statistical Yearbook of Lubelskie Voivodship (2013). Statistical Office in Lublin

Topograficzna Karta Królestwa Polskiego 1:126,000. (1843), Warszawa. Library of Faculty of Earth Sciences and Spatial Management MCSU

Wulf M, Sommer M, Schmidt R (2010) Forest cover changes in the Prignitz region (NE Germany) between 1790 and 1960 in relation to soils and other driving forces. Landsc Ecol 25:299-313

Zgłobicki W, Baran-Zgłobicka B (2012) Impact of loess relief on land use mosaic in SE Poland. Catena 96:76-82 